\title{
ANALIZA WYBRANYCH ZANIECZYSZCZEŃ POWIETRZA W 2018 R. NA TERENIE BIELSKA-BIAŁEJ
}

\author{
DARIUSZ GÓRA \\ Wydział Nauk Przyrodniczych, Uniwersytet Śląski \\ ul. Będzińska 60, 41-200 Sosnowiec \\ ORCID: 0000-0003-2495-3191
}

\begin{abstract}
Chemical composition of polluted atmospheric air has a negative impact on human health as well as animals, water and soil. In effect it causes respiratory system disease, blood system disease and cancers. Children and elderly people are among the most endangered as their immune system is weak. It is estimated that every year in Poland 45000 people die as a result of polluted air. On a global scale the number rises to 7 million people.
\end{abstract}

The aim of this elaboration is to present the concentration of chemical elements and particles, such as: suspended dust $\mathrm{PM}_{10}$ and $\mathrm{PM}_{2.5}$, nitro dioxide sulphur and benzo(a)pyrene, and to prove their negative impact on the human body. The article includes data from the Provincial Inspectorate for Environmental Protection in Katowice, Delegature in Bielsko-Biała. The next stage was to prepare appropriate graphs that show the concentrations of elements and chemical compounds in the air in individual months in 2018. The conducted analysis showed that the average annual $\mathrm{PM}_{2.5}$ dust concentration was $36 \mu \mathrm{g} / \mathrm{m}^{3}, \mathrm{PM}_{10}$ suspended dust $37 \mu \mathrm{g} / \mathrm{m}^{3}$, benzo(a)pyrene $4.47 \mathrm{ng} / \mathrm{m}^{3}$ and nitrogen oxides $62 \mu \mathrm{g} / \mathrm{m}^{3}$. In order to improve the sanitary state of the atmospheric air in the city of Bielsko-Biała and other areas with a high degree of urbanization, first of all reduce the sources of low emissions, i.e. emission of harmful dusts and gases from low emitters, which include chimneys, e.g from single-family houses or townhouses. Literature data show that exposure of people to particulate matter, benzo (a) pyrene and nitric oxides is mainly associated with an increased risk of heartbeat, bronchopulmonary and lung cancer and asthma.

Keywords: polycyclic aromatic hydrocarbons $(\mathrm{PAH})$, particulate matter $\left(\mathrm{PM}_{10}\right.$ and $\left.\mathrm{PM}_{2.5}\right)$, benzo(a)pyrene

\section{WSTĘP}

Zanieczyszczenie powietrza atmosferycznego następuje wskutek wprowadzenia do niego substancji stałych, ciekłych lub gazowych w ilościach, które mogą oddziaływać szkodliwie na organizm człowieka, zwierzęcia, rośliny, wodę i powodować inne szkody w środowisku naturalnym. O jakości powietrza na danym obszarze decyduje zawartość w nim różnych substancji, których koncentracja jest wyższa od tej w warunkach naturalnych. Poziomy stężeń zanieczyszczeń w powietrzu wynikają bezpośrednio $\mathrm{z}$ wielkości emisji zanieczyszczeń do atmosfery oraz z warunków meteorologicznych (Juda-Rezler i in. 2010; Bokwa 2008). Decydujące znaczenie ma także wpływ zanieczyszczeń napływowych (transgranicznych) z obszarów sąsiednich. Na terenie miasta Bielska-Białej, jak i całego województwa śląskiego głównym źródłem zanieczyszczenia powietrza 
jest emisja antropogeniczna związana ze źródłami powierzchniowymi, punktowymi oraz liniowymi, przede wszystkim transport drogowy (Brzozowski i in. 2016).

W Polsce powietrze w wielu skupiskach ludzkich należy do najgorszych na terenie całej Unii Europejskiej. Szczególną uwagę zwraca się na pyły zawieszone $\left(\mathrm{PM}_{2,5} \mathrm{i} \mathrm{PM}_{10}\right)$, węglowodory aromatyczne, dioksyny, furany oraz metale ciężkie. Raporty Światowej Organizacji Zdrowia wykazują, iż spośród 50 najbardziej zanieczyszczonych miast Unii Europejskiej aż 33 zlokalizowane są w Polsce, a siedem znajduje się w pierwszej dziesiątce. Pośrednio z powodu niskiej emisji w Polsce każdego roku umiera około 45 tys. osób (Cholewiński i in. 2016).

Zgodnie z Rozporządzeniem Ministra Środowiska z dnia 24 sierpnia 2012 r. w sprawie poziomów niektórych substancji w powietrzu (Dz.U. z 2012 r., poz. 1031):

- średnioroczne dopuszczalne stężenie pyłu zawieszonego $\mathrm{PM}_{2,5}$ powinno wynosić do $20 \mu \mathrm{g} / \mathrm{m}^{3}$ (do osiągnięcia do dnia 1 stycznia $2020 \mathrm{r}$.) lub $25 \mu \mathrm{g} / \mathrm{m}^{3}$ (do dnia 1 stycznia 2015 r.),

- średnioroczne dopuszczalne stężenie pyłu zawieszonego $\mathrm{PM}_{10}$ nie powinno przekraczać $25 \mu \mathrm{g} / \mathrm{m}^{3}$,

- średnioroczne dopuszczalne stężenie benzo(a)pirenu powinno wynosić do $1 \mathrm{ng} / \mathrm{m}^{3}$.

Jakość powietrza ma ogromne znaczenie dla stanu zdrowia i spodziewanej długości życia ludzi. Wyniki badania prowadzonego w sześciu miastach Stanów Zjednoczonych dowiodły, że zanieczyszczenie powietrza atmosferycznego istotnie zwiększa ryzyko zachorowania na raka płuc oraz choroby serca i układu krążenia. Ryzyko zgonu rośnie wraz ze wzrostem ilości pyłów, węglowodorów aromatycznych, tlenków azotu i siarczanów w powietrzu (Dockery i in. 1993). Z badania prowadzonego w latach 1994-1998, przeprowadzone $\mathrm{z}$ udziałem 65 893 amerykańskich kobiet po menopauzie, wynika, że zwiększona w powietrzu atmosferycznym liczba cząstek pyłów o średnicy mniejszej niż $2,5 \mu \mathrm{m}$ zwiększa ryzyko chorób sercowo-naczyniowych i zgonu wśród kobiet po menopauzie (Miller i in. 2007).

Pyły zawieszone $\mathrm{PM}_{2,5}$ i $\mathrm{PM}_{10}$ to mikropyły o średnicy $2,5 \mu \mathrm{g}$ oraz $10 \mu \mathrm{g}$, które powstają w wyniku transportu samochodowego, emisji z palenisk domowych, przemysłu grzewczego czy używania kominków. Są to jedne z najgroźniejszych zanieczyszczeń dla zdrowia i życia człowieka. Stanowią mieszaninę cząstek fazy stałej i ciekłej, które mogą mieć różny skład i wielkość. Frakcja pyłu $\mathrm{PM}_{10}$ powstaje przede wszystkim w wyniku poruszania się pojazdów po nieutwardzonych nawierzchniach, ich kruszenia, rozdrabniania oraz $\mathrm{w}$ wyniku tzw. pylenia wtórnego. Frakcja pyłu zawieszonego $\mathrm{PM}_{2,5}$ powstaje głównie podczas spalania paliw w silnikach samochodowych, zakładach przemysłowych, paleniskach domowych oraz elektrociepłowniach (Radziszewska i in. 2015). 
Cząsteczki pyłów mogą łączyć się z różnymi związkami chemicznymi, takimi jaki: siarka, węglowodory aromatyczne, metale ciężkie, dioksyny, alergeny. Pył zawieszony jest bardzo lekki, dzięki temu może unosić się w powietrzu i wnikać bez problemu do pęcherzyków płucnych, a stamtąd dostawać się nawet do krwiobiegu. Najbardziej szkodliwy jest pył typu $\mathrm{PM}_{10}$. Ziarna pyłku o większych rozmiarach powodują podrażnienia i stany zapalne spojówek oraz błon śluzowych nosa i gardła. Ponadto osoby, które cierpią na choroby płuc czy serca, a także osoby starsze i dzieci odczuwają skutki narażenia na zanieczyszczenia pyłowe przez nasilenie objawów negatywnych czy złego samopoczucia, zmęczenia i problemów z oddychaniem, pogorszenia pracy serca, a także częstym zapadaniem na choroby związane $\mathrm{z}$ układem oddechowym (Anderson $\mathrm{i}$ in. 2011).

Pyły zawieszone wpływają również negatywnie na osoby aktywne fizycznie. Uprawianie sportu na świeżym powietrzu powoduje szybszy i głębszy oddech, a co za tym idzie - wdychanie większej ilości zanieczyszczonego szkodliwego pyłu. U osób starszych podwyższony poziom zanieczyszczeń wpływa na zwiększenie potrzeby hospitalizacji, a nawet zgon z powodu chorób płuc czy sercowo-naczyniowych. Długotrwała ekspozycja na wysokie stężenia pyłów zawieszonych $\mathrm{w}$ atmosferze skutkuje zwiększeniem prawdopodobieństwa wystąpienia przewlekłej zaporowej choroby płuc, a także zmniejsza sprawność i wydolność płuc u osoby poddanej szkodliwej ekspozycji. Krótkotrwałe narażenie na szkodliwe stężenie pyłów może nasilać objawy chorób płuc oraz serca, głównie są to zwiększona krzepliwość płuc oraz zaburzenia rytmu serca, a także zwiększa się prawdopodobieństwo infekcji górnych dróg oddechowych (Neupane i in. 2010; Pénard-Morand i in. 2010).

Związki zaabsorbowane przez pyły odznaczają się mutagennością i kancerogennością (dioksyny, związki nitrowe, metale ciężkie). Ponadto dioksyny mają zdolność do kumulacji zarówno w organizmach ludzkich, jak i zwierzęcych, co może powodować zatrucia i uszkodzenia wątroby, śledziony, trzustki oraz nerek. Wykazują również działanie teratogenne oraz wpływają na zakłócenie funkcji reprodukcyjnych. Z kolei metale ciężkie związane z pyłami zwiększają prawdopodobieństwo wystąpienia nowotworów, a także przyczyniają się do chorób układu nerwowego (Min i in. 2008; Edwards i in. 2010).

Z najnowszych badań Światowej Organizacji Zdrowia wynika wyraźny związek między PM i umieralnością już przy stężeniach niższych niż obecnie zalecane $\mathrm{PM}_{2,5}$ poniżej $10 \mu \mathrm{g} / \mathrm{m}^{3}$. W regionie europejskim WHO szacuje, że $20 \%$ wszystkich zgonów jest spowodowane narażeniem na szkodliwe czynniki środowiska. Podwyższone stężenie $\mathrm{PM}_{10}$ i $\mathrm{PM}_{2,5}$ w Polsce wpływa na zmniejszenie oczekiwanej długości życia o około dziewięć miesięcy. Pyły zawieszone wywołują ostre reakcje i infekcje układu oddechowego, zaostrzają przebieg chorób alergicznych (zwłaszcza astmy) i chorób serca, stanowią istotny czynnik ryzyka chorób nowotworowych układu oddechowego oraz są poważnym czynnikiem patogennym dla 
prawidłowego przebiegu ciąży, a wręcz mogą powodować przedwczesną śmierć. Przyjmuje się, że nie ma bezpiecznych dla zdrowia wartości stężeń pyłów zawieszonych w powietrzu (Ścibor i in. 2015; Dockery i in. 1993).

Nawet krótkoterminowa ekspozycja na pyły zawieszone wiąże się ze zwiększoną liczbą hospitalizacji i konsultacji lekarskich w szpitalnych oddziałach ratunkowych, wynikających z powikłań oddechowych i sercowo-naczyniowych. Dla Krakowa oszacowano, że z powodu zanieczyszczenia powietrza pyłem zawieszonym umiera rocznie kilkaset osób. Średnia liczba możliwych do uniknięcia zgonów na rok została oszacowana dla 2001 r. w zależności od poziomu redukcji zanieczyszczeń (średniorocznego stężenia $\mathrm{PM}_{2,5}$ ). Redukcja do pozio$\mathrm{mu} 25 \mu \mathrm{g} / \mathrm{m}^{3}$ zmniejszyłaby liczbę zgonów średnio o 232 , redukcja do poziomu $20 \mu \mathrm{g} / \mathrm{m}^{3}$ o 362 , do poziomu $15 \mu \mathrm{g} / \mathrm{m}^{3}$ o 492 , a do poziomu $10 \mu \mathrm{g} / \mathrm{m}^{3}$ o 612 (zalecenia WHO). Dodatkowo oszacowano, że statystyczny krakowianin żyłby średnio o rok dłużej, gdyby udało się zredukować średnie roczne stężenie pyłu $\mathrm{PM}_{2,5}$ do $15 \mu \mathrm{g} / \mathrm{m}^{3}$ (Petryk 2018).

Benzo(a)piren to główny przedstawiciel węglowodorów aromatycznych (WWA), które zaliczane są do tzw. trwałych związków organicznych. Do grupy tych związków (oprócz opisywanego) zalicza się: antracen, benzo(a)antracen, chryzen, benzo(b)fluoranten, benzo(k)fluoranten, dibenzo(ah)antracen, benzo(ghi)perylen oraz indeno(123)piren. WWA dostają się do organizmu człowieka trzema drogami - pokarmową, oddechową i przezskórną, przy czym drogę przezskórną uznaje się za najmniej istotną przy narażeniu środowiskowym (Trojanowska, Świetlik 2013).

Szacuje się, że dzienne pobranie benzo(a)pirenu wraz z żywnością wynosi przeciętnie 0,5-305 ng dla mieszkańca Stanów Zjednoczonych, 70-190 ng dla mieszkańca Iranu i Korei Południowej oraz odpowiednio: 160-320 ng, 73-140 ng i 4,2-35 ng dla mieszkańców następujących państw europejskich, odpowiednio: Włoch, Hiszpanii i Republiki Czeskiej (Choi i in. 2010). Z badań wynika, że dzienne pobranie wraz z żywnością mieszaniny ośmiu kancerogennych WWA w Polsce wynosi 3078 ng, podczas gdy średnie ich pobranie przez konsumentów państw Unii Europejskiej wynosi 1729 ng/dzień. Poszczególne związki należące do grupy wielopierścieniowych węglowodorów aromatycznych charakteryzują się zróżnicowaną lipofilnością (Wieczorek i in. 2011).

Wielopierścieniowe węglowodory aromatyczne są związkami wykazującymi udowodnione działanie mutagenne; wpływają one ponadto w sposób negatywny na przebieg procesów endokrynologicznych, reprodukcyjnych oraz rozwojowych. Jednak najistotniejszym efektem zdrowotnym narażenia organizmu człowieka na WWA jest udowodniony wpływ dziewięciu związków z tej grupy na inicjowanie procesu nowotworowego (Choi i in. 2010). Najsilniejszym działaniem kancerogennym charakteryzują się szczególnie dwa związki z grupy WWA - benzo(a)piren i dibenzo(a,h)antracen. Międzynarodowa Agencja Badań nad Rakiem (International Agency for Research on Cancer - IARC) 
zakwalifikowała benzo(a)piren do grupy związków wykazujących udowodnione działanie rakotwórcze (grupa 1). Związki rakotwórcze są substancjami działającymi bezprogowo, co wiąże się z ryzykiem powstania zmian nowotworowych przy narażeniu na każde stężenie substancji. Narażenie na benzo(a)piren drogą oddechową stwarza prawdopodobieństwo rozwoju nowotworów płuc. W przypadku ekspozycji zawodowej grupę szczególnego ryzyka stanowią pracownicy koksowni. W województwie śląskim, w populacji mężczyzn pochodzących $\mathrm{z}$ miast o wysokim stężeniu benzo(a)pirenu w powietrzu, a więc narażonych środowiskowo na związki WWA, obserwowany jest wysoki odsetek zachorowań na nowotwory płuc (Kapka i in. 2009).

Udowodniono również wpływ wielopierścieniowych węglowodorów aromatycznych na występowanie porodów przedwczesnych i zaburzeń związanych ze wzrostem płodu, jednak mechanizm tego działania nie został do końca poznany. Wiadome jest, że związki te wiążą się ze strukturą DNA łożyska, wykazując działanie mutagenne oraz stwarzając ryzyko poronień samoistnych we wczesnym okresie ciąży. Transport przezłożyskowy WWA inicjuje powstanie stresu oksydacyjnego, wpływającego negatywnie na układ nerwowy oraz hormonalny płodu (Li i in. 2011).

Badania przeprowadzone przez Choi i in. (2008) w latach 2000-2003 na dwóch kohortach kobiet ciężarnych (w Krakowie oraz w Nowym Jorku) wykazały istnienie zależności między prenatalnym narażeniem na WWA a obniżeniem wybranych parametrów fizycznych $\mathrm{w}$ grupie noworodków pochodzących z ciąż donoszonych. Masa ciała noworodków była niższa średnio o $68,75 \mathrm{~g}$ w przypadku grupy krakowskiej oraz o 177,57 g w przypadku grupy z Nowego Jorku. Obniżenie długości ciała noworodka wynosiło $0,48 \mathrm{~cm}$, a obwód główki był mniejszy o $0,21 \mathrm{~cm}$ w przypadku grupy krakowskiej.

Narażenie na benzo(a)piren podczas procesu organogenezy prowadzi do znaczącego obniżenia masy i długości ciała płodu. Mózg oraz układ nerwowy płodu są organami najbardziej wrażliwymi na oddziaływanie wspomnianych związków (Sanyal, Li 2007). Potwierdzeniem tej hipotezy są również badania Wormleya $\mathrm{i}$ in. (2004). Wykazano w nich, że przezłożyskowe narażenie na benzo(a)piren wpływa negatywnie na receptory umieszczone w hipokampie - strukturze znajdującej się w płacie skroniowym kory mózgowej, odpowiedzialnej za procesy zapamiętywania i uczenia się.

Z badań Vassileva (2001) wynika istnienie zależności między narażeniem kobiet ciężarnych na pył zawierający wielopierścieniowe węglowodory aromatyczne w zakresie stężeń od $0,269 \mu \mathrm{g} / \mathrm{m}^{3}$ do $2,830 \mu \mathrm{g} / \mathrm{m}^{3}$ powietrza a wczesną umieralnością noworodków oraz występowaniem urodzeń przedwczesnych i urodzeń dzieci z niską urodzeniową masą ciała.

W badaniach prowadzonych w dużych miastach aglomeracji śląskiej wykazano wysoką korelację między zawartością benzo(a)pirenu w powietrzu a liczbą urodzeń dzieci z niską masą urodzeniową (Rusin 2014). 


\section{CEL PRACY, MATERIAŁY I METODY}

Za cele pracy przyjęto ocenę poziomu zanieczyszczenia powietrza atmosferycznego pyłu zawieszonego $\mathrm{PM}_{2,5}$ i $\mathrm{PM}_{10}$ oraz benzo(a)pirenu w 2018 r. na terenie miasta Bielsko-Biała, próbę wykazania ich negatywnego wpływu na organizm oraz przedstawienie sposobów zapobiegania niskiej emisji.

Powierzchnia miasta wynosi 124,51 km². Liczba ludności w 2018 r. wynosiła 171277 mieszkańców (www.katowice.stat.gov.pl). Miasto Bielsko-Biała leży w południowej części województwa śląskiego, na granicy Śląska Cieszyńskiego i Małopolski. Jednak większa jego część znajduje się na Pogórzu Śląskim, które jest częścią makroregionu Pogórza Zachodniobeskidzkiego. Klimat miasta jest zróżnicowany, ponieważ jest ono zlokalizowane na terenie dwóch regionów klimatycznych: podkarpackiego (pogórze) i karpackiego (góry). Klimat ten charakteryzuje się dużym stopniem nieregularnych stanów pogody i dużymi wahaniami temperatury w ciągu roku (Barański 2007; Kondracki 2002).

$\mathrm{Na}$ terenie miasta znajdują są trzy stacje, na których dokonuje się monitoringu jakości powietrza atmosferycznego. Przy ul. Kossak-Szczuckiej (południowo-zachodnia część miasta) jest stacja, na której przeprowadza się pomiar manualny oraz automatyczny (kod stacji: SlBielbBiel_kossa). Stacja jest usytuowana w miejscu, gdzie występuje ruch o małym natężeniu, blisko ulic osiedlowych i domów jednorodzinnych. Nie ma tu terenów przemysłowych, ale przebiega ruchliwa obwodnica (al. Andersa). Druga stacja monitoringu powietrza znajduje się przy ul. Sterniczej (kod stacji: SlBielbBiel_stern), na której od 2011 r. dokonuje się pomiaru pasywnego dla benzenu oraz od 2010 r. pomiaru manualnego dla pyłu zawieszonego $\mathrm{PM}_{2,5}$. Trzecia stacja monitoringu jest przy ul. Partyzantów (kod stacji:SlBielPartyz). Dokonuje się tam pomiaru automatycznego dla tlenku węgla, tlenku azotu, dwutlenku azotu oraz pyłu zawieszonego $\mathrm{PM}_{2,5}$ (ryc. 1).

Monitoring jakości powietrza na terenie miasta Bielsko-Biała realizowany jest przez Wojewódzki Inspektorat Ochrony Środowiska w Katowicach, Delegaturę w Bielsku-Białej. Analiza zanieczyszczeń powietrza dokonywana jest metodą manualną. Polega ona na zastosowaniu urządzeń, do których zasysane jest powietrze atmosferyczne. Czas oczekiwania na wyniki wynosi około trzech tygodni.

Bielsko-Biała to główne miasto Beskidzkiego Okręgu Przemysłowego (jedno z 11 okręgów przemysłowych w Polsce). W okręgu tym rozwija się zwłaszcza przemysł maszynowy, włókienniczy, samochodowy, metalurgiczny oraz spożywczy. Liczne zakłady przemysłowe zlokalizowane są przede wszystkim w dzielnicy Wapienicy i Komorowic. Największe zakłady przemysłowe to: Fiat Auto Poland, Fiat-GM Powertrain Polska, Nemak Poland, Eaton Automotive Systems, Alder Polska, Magneti Marelli, Techmex, Hutchinson Poland oraz Zakłady Tłuszczowe Bielmar (Haczek 2014). 


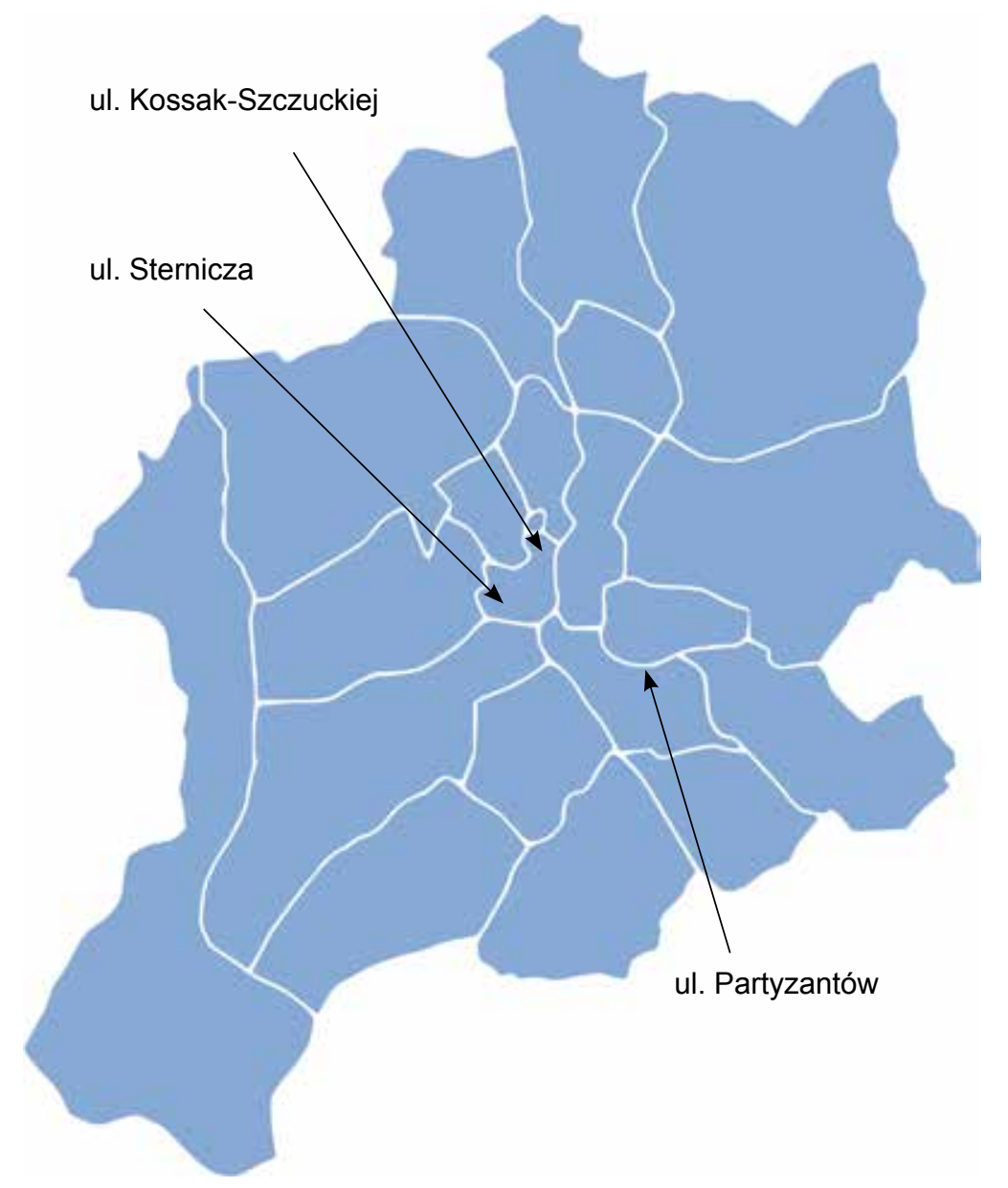

Ryc. 1. Lokalizacja stacji monitoringu jakości powietrza w Bielsku-Białej

Fig. 1. Location of the air quality monitoring station in Bielsko-Biała

Bielsko-Biała należy do najbardziej zanieczyszczonych miast w Polsce, jak i w Europie (Brzozowski i in. 2016). Największy wpływ na zanieczyszczone powietrze mają lokalne centralne ogrzewanie $(\mathrm{CO})$ używane w gospodarstwach domowych oraz MŚP (małe i średnie przedsiębiorstwa) spalające węgiel w celach grzewczych i technologicznych. Źródłami zanieczyszczeń powietrza jest również komunikacja samochodowa i energetyka, głównie niska emisja z lokalnych systemów grzewczych. Obecna organizacja ruchu pojazdów samochodowych na terenie Bielska-Białej jest niekorzystna i sprzyja powstawaniu smogu fotochemicznego w okresie sprzyjających temperatur. Nie bez znaczenia jest również emisja pochodzenia energetycznego z Górnośląskiego Obszaru Przemysłowego, Rybnickiego Okręgu Węglowego oraz Zagłębia Ostrawsko-Karwińskiego (Barański 2007). 
Średnioroczne stężenia zanieczyszczeń uzyskano na podstawie liczby dokonanych pomiarów, a następnie obliczono pomiary zaburzone, co przedstawia się następująco:

- benzo(a)piren; liczba ważnych pomiarów 327, a procent (\%) ważnych danych wynosi 98 ,

- pył zawieszony $\mathrm{PM}_{10}$; liczba ważnych pomiarów 332, a procent (\%) ważnych danych wynosi 91 ,

- pył zawieszony $\mathrm{PM}_{2,5}$; liczba ważnych pomiarów 356 , a procent (\%) ważnych danych wynosi 98 (www.katowice.pios.gov.pl).

Pomiar manualny benzo(a)pirenu, pyłu zawieszonego $\mathrm{PM}_{2,5}$ oraz pyłu zawieszonego $\mathrm{PM}_{10}$ przeprowadzany jest przy użyciu urządzenia TECORA.

$\mathrm{W}$ artykule uwzględniono dane pochodzące $\mathrm{z}$ Wojewódzkiego Inspektoratu Ochrony Środowiska w Katowicach. Dalszym etapem było przedstawienie odpowiednich wykresów, które obrazują stężenia wymienionych związków chemicznych w powietrzu w poszczególnych miesiącach w $2018 \mathrm{r}$. Dane te pochodzą z 4 marca 2019 r. Poza tym uwzględniono średnioroczne stężenia pyłu $\mathrm{PM}_{10}$, pyłu $\mathrm{PM}_{2,5}$ oraz benzo(a)pirenu począwszy od $2014 \mathrm{r}$.

Metoda pomiarów pyłu zawieszonego polega na użyciu poborników pyłowych, specjalnych urządzeń, do których zasysane jest powietrze atmosferyczne. Montowane są jednorazowe filtry, które przed założeniem do pobornika są ważone. Po 14 dniach, czyli po dobowej ekspozycji każdego filtra, wszystkie są wyjmowane, przewożone do laboratorium i ważone po raz drugi, już jako filtry po tzw. ekspozycji. $Z$ różnic mas przed i po ekspozycji filtra wyliczane są stężenia pyłów.

\section{WYNIKI I WNIOSKI}

$\mathrm{Na}$ terenie Bielska-Białej średnioroczne stężenie pyłu zawieszonego $\mathrm{PM}_{2,5}$ wynosiło $36 \mu \mathrm{g} / \mathrm{m}^{3}$ (ryc. 2). Najwyższe miesięczne stężenie odnotowano w styczniu i lutym $\left(79 \mu \mathrm{g} / \mathrm{m}^{3}\right)$ oraz w marcu $\left(71 \mu \mathrm{g} / \mathrm{m}^{3}\right)$. Średnie miesięczne stężenia pyłów $\mathrm{PM}_{2,5} \mathrm{~W}$ okresie zimowym są ponad czterokrotnie wyższe niż w miesiącach letnich. Najwyższe dzienne stężenie odnotowano: 6 marca $\left(240 \mu \mathrm{g} / \mathrm{m}^{3}\right)$, 5 marca $\left(197 \mu \mathrm{g} / \mathrm{m}^{3}\right), 10$ lutego $\left(196 \mu \mathrm{g} / \mathrm{m}^{3}\right), 4$ marca $\left(179 \mu \mathrm{g} / \mathrm{m}^{3}\right), 3$ marca $(147$ $\left.\mu \mathrm{g} / \mathrm{m}^{3}\right), 19$ grudnia $\left(138 \mu \mathrm{g} / \mathrm{m}^{3}\right), 9$ lutego $\left(135 \mu \mathrm{g} / \mathrm{m}^{3}\right), 20$ listopada $\left(130 \mu \mathrm{g} / \mathrm{m}^{3}\right)$ oraz 26 stycznia $\left(116 \mu \mathrm{g} / \mathrm{m}^{3}\right)$.

W 2018 r. w Bielsku-Białej średnioroczne stężenie pyłu zawieszonego $\mathrm{PM}_{10}$ wynosiło $37 \mu \mathrm{g}^{3}$ (ryc. 3). Najwyższą miesięczną średnią odnotowano w lutym $\left(76 \mu \mathrm{g} / \mathrm{m}^{3}\right)$, marcu $\left(66 \mu \mathrm{g} / \mathrm{m}^{3}\right)$ oraz w listopadzie $\left(51 \mu \mathrm{g} / \mathrm{m}^{3}\right)$. Dopuszczalna częstość 24-godzinnego przekraczania poziomu dopuszczalnego pyłu zawieszonego $\mathrm{PM}_{10} \mathrm{~W}$ roku kalendarzowym wynosi 35 razy. W 2018 r. liczba takich dni wynosiła 67 na terenie miasta Bielska-Białej i w porównaniu z 2017 r. liczba 


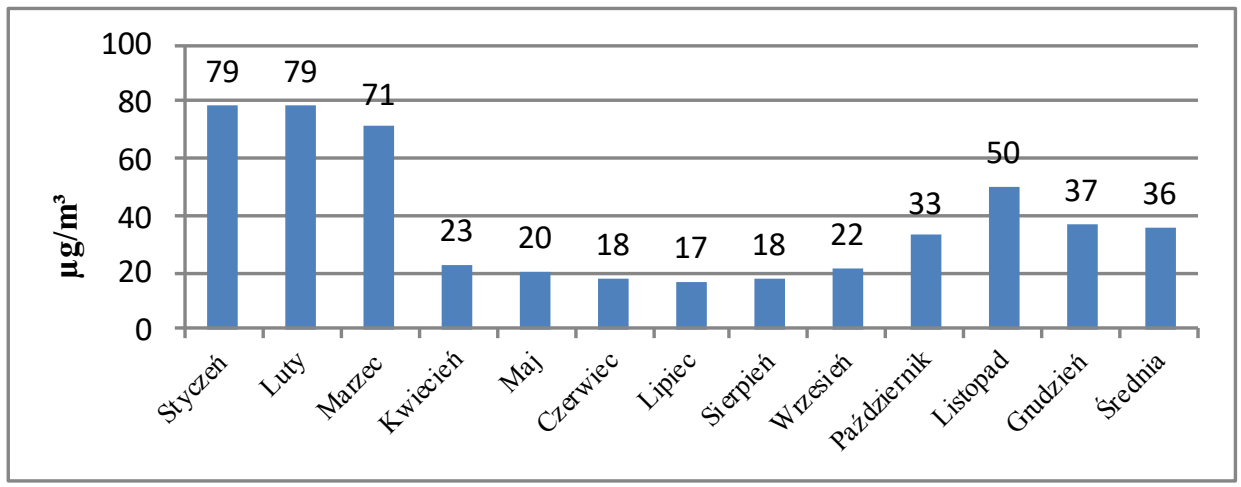

Ryc. 2. Miesięczne stężenia pyłu zawieszonego PM2,5 na terenie miasta Bielska-Białej w 2018 r.

Fig. 2. Monthly concentrations of PM2.5 in the city of Bielsko-Biała in 2018

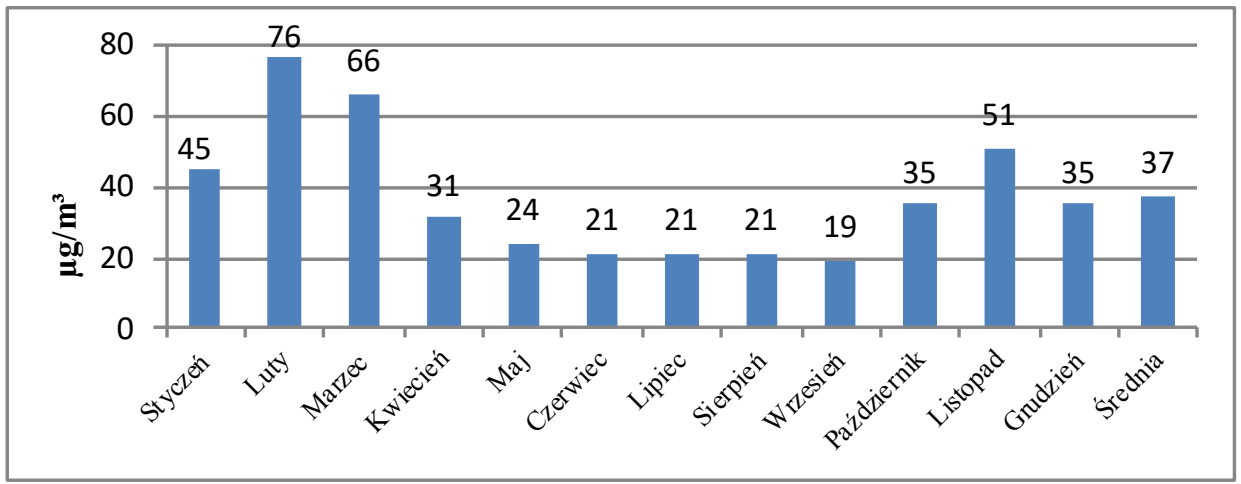

Ryc. 3. Miesięczne stężenia pyłu zawieszonego PM10 na terenie miasta Bielska-Białej w 2018 r.

Fig. 3. Monthly concentrations of PM10 in the city of Bielsko-Biała in 2018

ta zmalała o pięć przekroczeń. Najwyższe 24-godzinne stężenia odnotowano: 6 marca $\left(208 \mu \mathrm{g} / \mathrm{m}^{3}\right), 10$ lutego $\left(205 \mu \mathrm{g} / \mathrm{m}^{3}\right), 5$ marca $\left(202 \mu \mathrm{g} / \mathrm{m}^{3}\right), 23$ listopada $\left(137 \mu \mathrm{g} / \mathrm{m}^{3}\right), 12$ lutego $\left(129 \mu \mathrm{g} / \mathrm{m}^{3}\right), 19$ grudnia $\left(117 \mu \mathrm{g} / \mathrm{m}^{3}\right)$ oraz 26 stycznia $\left(113 \mu \mathrm{g} / \mathrm{m}^{3}\right)$.

W 2018 r. jego średnioroczne stężenie na terenie Bielska-Białej wynosiło $7,18 \mathrm{ng} / \mathrm{m}^{3}$ (ryc. 4). Najwyższe średnie miesięczne stężenie odnotowano w lutym $\left(15,13 \mathrm{ng} / \mathrm{m}^{3}\right)$ oraz w styczniu $\left(10,39 \mathrm{ng} / \mathrm{m}^{3}\right)$. Najwyższe dzienne stężenia odnotowano w dniach: od 5 do 11 listopada $\left(20,13 \mathrm{ng} / \mathrm{m}^{3}\right)$, od 21 do 27 stycznia $\left(17,22 \mathrm{ng} / \mathrm{m}^{3}\right)$, od 12 do 18 lutego $\left(16,22 \mathrm{ng} / \mathrm{m}^{3}\right)$, od 1 do 4 marca $\left(15,26 \mathrm{ng} / \mathrm{m}^{3}\right)$, od 19 do 25 marca $\left(15,09 \mathrm{ng} / \mathrm{m}^{3}\right)$ oraz od 17 do 23 grudnia $\left(13,59 \mathrm{ng} / \mathrm{m}^{3}\right)$.

Na terenie miasta Bielska-Białej od roku 2014 do 2017 zauważa się wzrost średniorocznego stężenia benzo(a)pirenu (oprócz 2018 r., kiedy średnia ta wynosi $\left.4,47 \mathrm{ng} / \mathrm{m}^{3}\right)$. Najwyższe stężenie odnotowano w 2017 r. $\left(7,18 \mathrm{ng} / \mathrm{m}^{3}\right)$. 


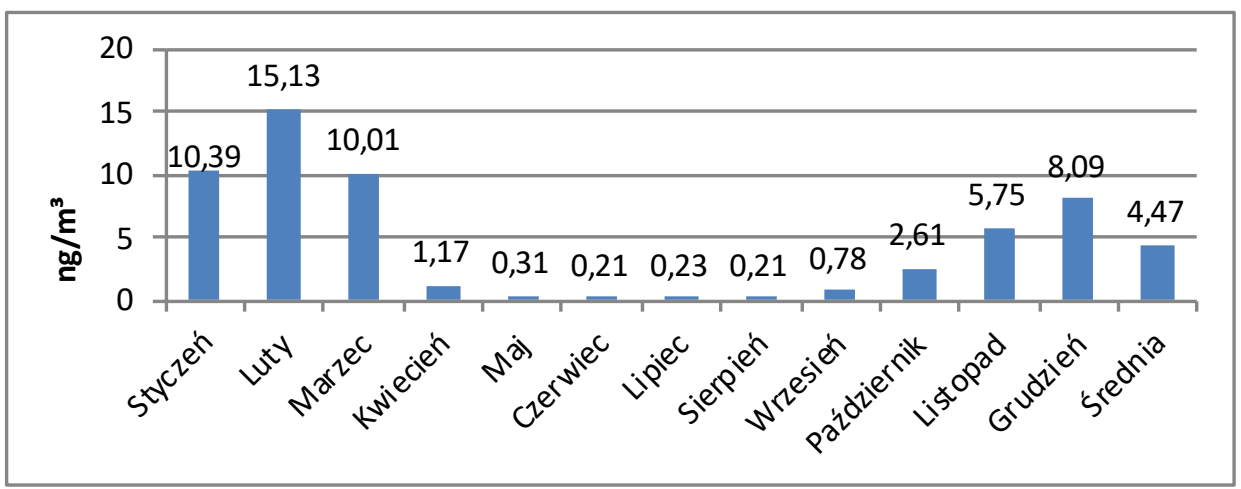

Ryc. 4. Miesięczne stężenia benzo(a)pirenu na terenie miasta Bielska-Białej w $2018 \mathrm{r}$.

Fig. 4. Monthly concentrations of benzo(a)pyrene in the city of Bielsko-Biała in 2018

Średnioroczne stężenia pyłu zawieszonego $\mathrm{PM}_{10}$ utrzymują się na stałym poziomie $\left(37 \mu \mathrm{g} / \mathrm{m}^{3}\right)$ oprócz roku 2015 , w którym nastąpił spadek o $2 \mu \mathrm{g} / \mathrm{m}^{3}$. Średnioroczne stężenie pyłu zawieszonego $\mathrm{PM}_{2,5}$ wykazuje tendencję wzrostową od 2015 r. (ryc. 5).

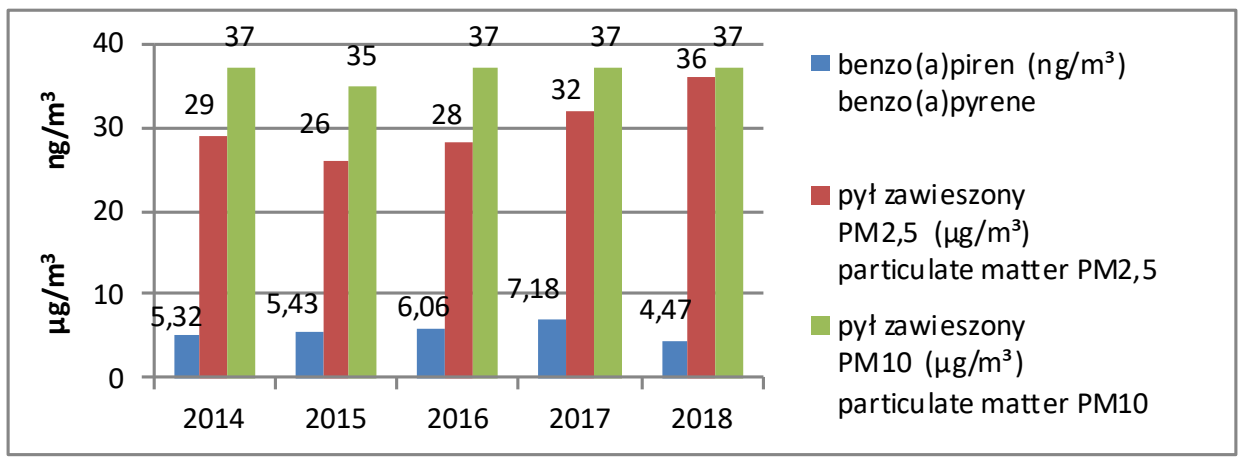

Ryc. 5. Roczne stężenia benzo(a)pirenu, pyłu zawieszonego $\mathrm{PM}_{2,5}$ i pyłu zawieszonego $\mathrm{PM}_{10}$ w latach 2014-2018

Fig. 5. Annual concentrations benzo(a)pyrene, particulate matter $\mathrm{PM}_{10}$ and $\mathrm{PM}_{2.5}$ in Bielsko-Biała in 2014-2018

\section{WARUNKI ATMOSFERYCZNE W BIELSKU-BIAŁEJ W 2018 R.}

Warunki meteorologiczne poza warunkami emisji, rzeźbą terenu i właściwościami zanieczyszczeń są podstawowym czynnikiem wpływającym na rozprzestrzenianie zanieczyszczeń i na jakość powietrza (Wielgosiński i in. 2018).

Rok 2018 był rokiem cieplejszym od wielolecia (z wyjątkiem lutego i marca, które były znacznie chłodniejsze) i z mniejszą ilością opadów w pierwszym 
kwartale i sezonie letnim, a także z niższą prędkością wiatru w pierwszym kwartale. Przełożyło się to na jakość powietrza, tj. na wystąpienie epizodów pyłowych w pierwszym kwartale roku, a także na większą liczbę dni z przekroczeniami poziomów stężeń monitorowanych zanieczyszczeń w sezonie zimowym i większą liczbę dni z przekroczeniami ozonu troposferycznego w sezonie letnim.

Na jakość powietrza atmosferycznego w Bielsku-Białej w 2018 r. decydujący wpływ miało występowanie trzech epizodów wysokich stężeń powietrza, w których stężenia dobowe pyłu zawieszonego $\mathrm{PM}_{10}$ są wyższe niż $150 \mu \mathrm{g} / \mathrm{m}^{3}$.

W pierwszym okresie (od 6 do 12 lutego) miasto Bielsko-Biała znajdowało się głównie w zasięgu układu podwyższonego ciśnienia, przerywanego okresowo napływem ośrodków niżowych. W omawianym okresie przeważało zachmurzenie umiarkowane i duże z większymi przejaśnieniami. Wiatr był słaby, okresami umiarkowany, przeważnie ze zmiennych kierunków. Najwyższą maksymalną prędkość wiatru w Bielsku-Białej odnotowano 12 lutego, o wysokości $8,0 \mathrm{~m} / \mathrm{s}$. W dniu 6 lutego w Bielsku-Białej odnotowano zarówno najniższą średnią dobową wartość temperatury powietrza $\left(-8,4^{\circ} \mathrm{C}\right)$, jak i najniższą wartość temperatury minimalnej $\left(-14,8^{\circ} \mathrm{C}\right)$. Poza tym 6 lutego w omawianym mieście odnotowano największą amplitudę temperatury powietrza dla tego okresu o wysokości $11,7^{\circ} \mathrm{C}$. W tym też okresie w Bielsku-Białej dominowały wiatry z kierunków południowo-zachodnich ( $26 \%$ obserwacji) i zanotowano $4,2 \%$ udziału cisz (Roczna ocena jakości..., 2019).

W drugim okresie (od 1 do 6 marca) warunki atmosferyczne w całym województwie śląskim w głównej mierze kształtowały układy niskiego ciśnienia. Do końca omawianego okresu województwo śląskie pozostawało w zasięgu stacjonarnego niżu znad Wysp Brytyjskich w strefie frontu okluzji, w ciepłej, polarno-morskiej masie powietrza. Przeważał wiatr słaby i umiarkowany, ze zmiennych kierunków: początkowo wschodni, zmieniający się na północny i północno-wschodni, a pod koniec okresu południowo-zachodni, w górach porywisty (od 17 do $19 \mathrm{~m} / \mathrm{s}$ ). Największa maksymalna wartość prędkości wiatru w Bielsku-Białej wynosiła $8,0 \mathrm{~m} / \mathrm{s}$ w dniu 3 marca, a najniższa wartość średniej dobowej temperatury powietrza $-12,4^{\circ} \mathrm{C}$ w dniu 1 marca. Udział cisz w tym okresie wynosił 4,3\% (Roczna ocena jakości..., 2019).

W trzecim okresie (od 8 do 10 listopada) trwania epizodu wysokich stężeń zanieczyszczeń powietrza, w których stężenia dobowe pyłu $\mathrm{PM}_{10}$ są wyższe niż $150 \mathrm{w} \mu \mathrm{g} / \mathrm{m}^{3}$, województwo śląskie znajdowało się w słabogradientowym obszarze między rozległym niżem znad Atlantyku a wyżem rozciągającym się od północno-zachodniej części Rosji po Morze Czarne. Początkowo z południowego zachodu napływało powietrze polarno-morskie, które następnie zostało przetransformowane $\mathrm{w}$ masę ciepłego powietrza zwrotnikowego. W górach występował wiatr dość silny i porywisty, z kierunku południowego i południowo-zachodniego. Najwyższą średnią wartość temperatury powietrza w Bielsku-Białej w omawianym okresie odnotowano 8 listopada i wynosiła ona $10,3^{\circ} \mathrm{C}$. 
W tym czasie dominowały wiatry z kierunków wschodnich, a udział cisz wynosił 5,6\% (Roczna ocena jakości..., 2019).

Najniższa średnia miesięczna temperatura powietrza w 2018 r. w Bielsku-Białej wynosiła $-3,7^{\circ} \mathrm{C}$ w lutym, a najwyższa $20,5^{\circ} \mathrm{C}$ w sierpniu. Najwyższą miesięczną sumę opadów odnotowano we wrześniu $137,9 \mathrm{~mm}$, w czerwcu $135,5 \mathrm{~mm}$ oraz w lipcu 126,3 mm, a najniższą w kwietniu 10,3 mm i w listopadzie 10,6 mm. Najwyższa średnia miesięczna (styczeń) prędkość wiatru wynosiła $4,6 \mathrm{~m} / \mathrm{s}$, a najmniejsza $2,6 \mathrm{~m} / \mathrm{s}$ (od czerwca do sierpnia). Wszystkie warunki meteorologiczne odniesiono do wartości z okresu wieloletniego 1981-2010 (tab.).

\section{PODSUMOWANIE}

Miasto Bielsko-Biała reprezentuje warunki aerosanitarne typowe dla obszarów zurbanizowanych, będące wypadkową emisji antropogenicznej związanej z funkcjonowaniem sektora komunalno-bytowego, przemysłowego oraz transportu. Ponadto teren miasta narażony jest na adwekcję zanieczyszczeń z ościennych, wysoko uprzemysłowionych ośrodków. Miasta takie jak Tychy, Jastrzębie-Zdrój, a także miasta należące do Górnośląskiego Okręgu Przemysłowego zostały zaliczone do miast o dużej skali zagrożenia środowiska emisją zanieczyszczeń powietrza. W konsekwencji powoduje to złą jakość powietrza na terenie miasta, potęgowaną wzmożoną konsumpcją paliw stałych w sezonie grzewczym w lokalnych kotłowniach i paleniskach domowych (Cembrzyńska i in. 2012).

Dotrzymanie standardów jakości powietrza, zwłaszcza w sezonie zimowym, jest problemem wielu miast europejskich, a uzyskane w niniejszej pracy wyniki badań wykazują zgodność z badaniami innych autorów (Houthuijs i in. 2001). Wieloośrodkowe badania prowadzone w pięciu państwach Europy Środkowej i Wschodniej (Polska, Czechy, Bułgaria, Rumunia, Słowacja) wykazały, że stężenia pyłu zawieszonego $\mathrm{PM}_{10}$ oraz $\mathrm{PM}_{2,5}$ mierzone w okresie zimowym,są średnio dwu-, trzykrotnie wyższe niż w okresie letnim (Cembrzyńska i in. 2012). $\mathrm{Na}$ terenie Bielska-Białej średnie miesięczne stężenia pyłów $\mathrm{PM}_{2,5} \mathrm{~W}$ okresie zimowym w 2018 r. są ponad czterokrotnie wyższe niż w miesiącach letnich (ryc. 2), a średnie miesięczne stężenie pyłu $\mathrm{PM}_{10}$ trzy-, czterokrotnie wyższe (ryc. 3). W przypadku benzo(a)pirenu nastąpiło blisko pięciokrotne przekroczenie średniorocznej dopuszczalnej normy (ryc. 4).

Problem zanieczyszczenia powietrza dotyczy praktycznie wszystkich dużych miast w Polsce i w Europie. Według danych przedstawionych przez Europejską Agencję Środowiska (EEA, 2015) kwestia podwyższonych stężeń $\mathrm{PM}_{10}$ w Europie nie ogranicza się tylko do środkowej części kontynentu (gdzie obserwuje się większy udział materii węglowej w PM), ale można ją uznać za bardziej rozpowszechniony problem (Czernecki i in. 2017; EEA, 2015). 


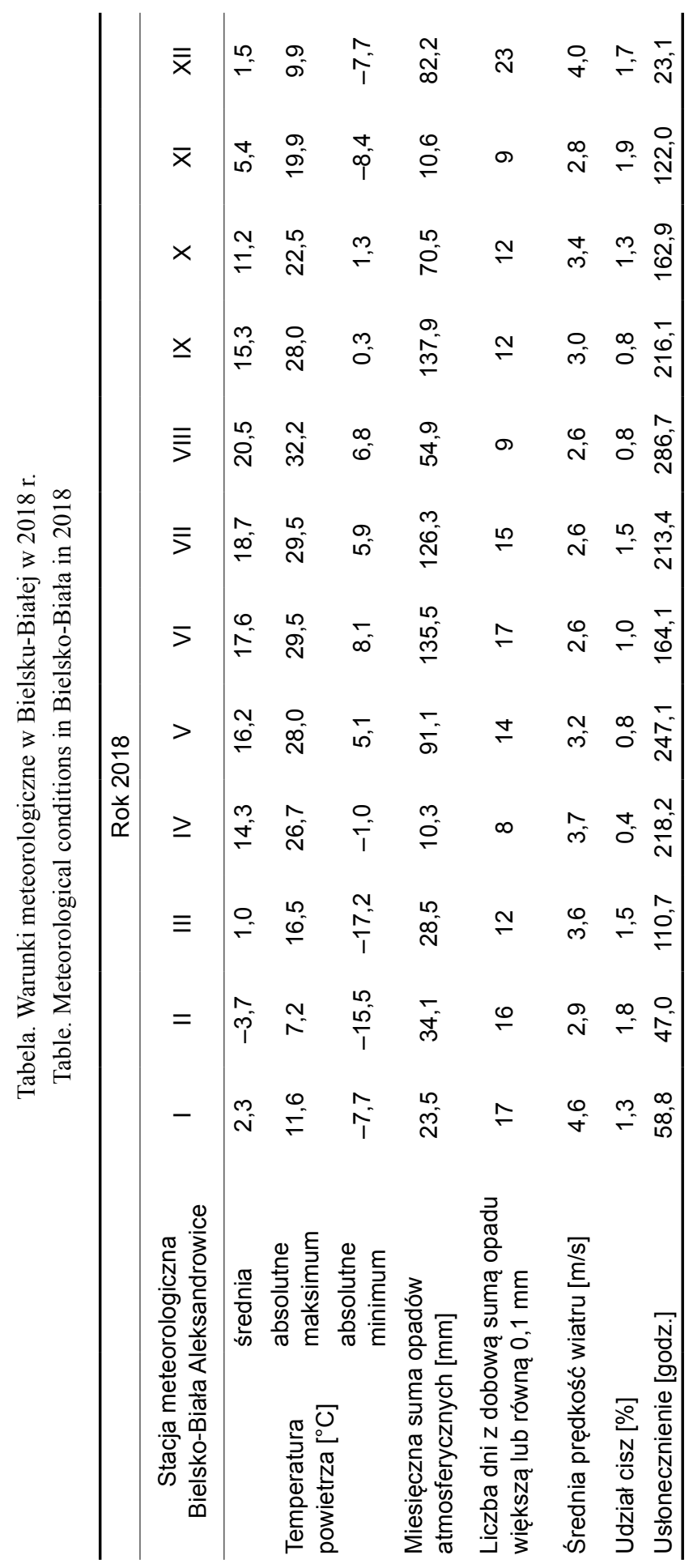


Jednym z najbardziej zanieczyszczonych powietrzem miast w Europie jest Kraków (Ćwiek i in. 2015). Średnie miesięczne stężenia pyłu PM PM $_{2,5}$ w Krakowie ulega zmianie w przebiegu rocznym. Maksimum stężenia występuje w półroczu chłodnym, natomiast minimum w półroczu ciepłym. Różnice stężenia $\mathrm{PM}_{2,5}$ między półroczem chłodnym i ciepłym wynikają przede wszystkim ze wzrostu spalania węgla $\mathrm{w}$ paleniskach domowych oraz $\mathrm{z}$ częstego pojawiania się niekorzystnych dla dyspersji zanieczyszczeń stanów równowagi termodynamicznej atmosfery w półroczu chłodnym oraz korzystnych warunków do rozwoju konwekcji w ciepłym półroczu. Pewne znaczenie może mieć też napływ zanieczyszczeń pyłowych spoza obszaru aglomeracji krakowskiej (Jędryszkiewicz i in. 2016: Bokwa 2008).

Podobne wyniki uzyskano dla województwa dolnośląskiego i pomorskiego, gdzie badano średnioroczne stężenia $\mathrm{PM}_{10} \mathrm{i}$ benzo(a)pirenu (Czarnecka $\mathrm{i}$ in. 2015; Leśniok i in. 2009).

W celu ograniczenia emisji pyłów i gazów pochodzących ze źródeł niskiej emisji powinny być wdrażane różnego rodzaju działania naprawcze. Mogą one obejmować:

- likwidację kotłów węglowych i zastępowanie ich proekologicznymi źródłami energii (np. na zasadzie udzielania dotacji w wysokości 100\% zwrotów kosztów inwestycji),

- wprowadzenie rozwiązań komunikacyjnych, które doprowadzą do obniżenia emisji liniowej,

- ograniczenie wjazdu do centrum dla samochodów powyżej 3,5 tony,

- ograniczenie emisji z indywidualnych systemów ogrzewania mieszkań,

- likwidację starych kotłów (chodzi o indywidualne kotły węglowe) oraz zastępowanie ich podłączeniem do sieci ciepłowniczych (tam, gdzie jest to możliwe), ogrzewaniem gazowym, olejowym albo elektrycznym lub wykorzystanie alternatywnych sposobów pozyskiwania energii $\mathrm{w}$ postaci pomp ciepła czy kolektorów słonecznych, które stanowią uzupełniające źródła pozyskiwania energii cieplnej,

- edukację ekologiczną,

- rozwój miejskiej sieci ciepłowniczej, modernizację centralnej ciepłowni oraz likwidację osiedlowych i lokalnych kotłowni węglowych,

- ocieplanie obiektów, wymianę okien, drzwi zewnętrznych oraz oświetlenia na energooszczędne,

- promowanie transportu drogowego opartego na pojazdach zasilanych gazem LPG,

- przebudowę systemów wentylacji i klimatyzacji z zastosowaniem automatyki pogodowej, stabilizującej temperaturę wewnątrz budynku bez względu na warunki zewnętrzne i systemów zarządzania budynkiem,

- ograniczenie ruchu samochodów w centrach miast przez zastosowanie odpowiednich rozwiązań, takich jak: budowa linii dla miejskiego transportu 
szynowego, budowa pasów ruchu przeznaczonych tylko dla autobusów, rozpowszechnianie stacji szybkiego ładowania akumulatorów w autach elektrycznych, rezerwowanie części miejsc parkingowych dla samochodów z napędem hybrydowym, poprawa efektywności wykorzystania istniejącej infrastruktury dzięki wprowadzeniu rozwiązań pozwalających na poprawę instalacji świetlnej sterującej ruchem ulicznym, poprawa infrastruktury drogowej w wyniku budowania obwodnic, rozbudowa ścieżek rowerowych i infrastruktury dla pieszych, wdrożenie taniej lub darmowej komunikacji miejskiej, wprowadzenie stref płatnego parkowania, wyłączenie części dróg dla ruchu samochodów osobowych, wyznaczenie darmowych miejsc parkingowych dla samochodów elektrycznych, zakaz wjazdu pojazdów niespełniających określonych norm środowiskowych oraz zapewnienie płynności ruchu pojazdów (Dzikuć 2017).

Dane literaturowe dowodzą, że narażenie ludzi na ekspozycję pyłu zawieszonego, benzo(a)pirenu oraz tlenków azotu wiąże się głównie ze zwiększonym ryzykiem wystąpienia zaburzeń bicia serca, nowotworów złośliwych oskrzeli i płuc oraz astmy.

\section{LITERATURA}

Anderson Z.J., Hvidberg M., Jensen S.S., Ketzel M., Loft S., Sorensen M., Tionneland M., Raaschou-Nielsen O., 2011: Chronic obstructive pulmonary disease and long-term exposure to traffic-related air pollution: a cohort study. American Journ. Respiratory Critical Care Medicine, 183, 4, 455-461.

Barański M., 2007: Beskid Śląski. Przewodnik. Ofic. Wyd. REWASZ, Pruszków.

Bokwa A., 2008: Environmental impacts of long-term air pollution changes in Kraków. Polish Journ. of Environmental Stud., 17, 5, 673-686.

Brzozowski K., Maczyński A., Ryguła A., 2016: Wyniki monitoringu jakości powietrza w warunkach porannego i popoludniowego szczytu komunikacyjnego dla obszaru miasta Bielsko-Biata. Autobusy, 11, 38-44.

Cembrzyńska J., Krakowiak E., Brewczyński P., 2012: Zanieczyszczenie powietrza pyłem zawieszonym PM10 oraz PM2,5 w warunkach silnej antropopresji na przyktadzie miasta Sosnowiec. Med.. Środowiskowa, 15, 4, 31-38.

Choi H., Harrison R., Komulainen H., Juana M., 2010: Polycyclic aromatic hydrocarbons. Guidelines for Indoor Air Quality: Selected Pollutants. World Health Organization, Geneva.

Cholewiński M., Kamiński M., Pospolita W., 2016: Zagrożenia dla zdrowia i życia człowieka wynikajace ze stosowania wybranych paliw $w$ indywidualnych instalacjach grzewczych. Kosmos, 65, 4, 477-486.

Czarnecka M., Nidzgorska-Lencewicz J., 2015: Application of cluster analysis in defining the meteorological conditions shaping the variability of PM10 concentration. Roczn. Ochrona Środowiska, 17, 40-61.

Czernecki B., Półrolniczak M., Kolendowicz L., Marosz M., Kendzierski S., Pilguj N., 2017: Influence of the atmospheric conditoions on PM $M_{10}$ concentriatons in Poznań. Journ. of Atm Chem., 74, 1, 115-139.

Ćwiek A., Majewski G., 2015: Wptyw elementów meteorologicznych na ksztattowanie się stężeń zanieczyszczé́ powietrza na przykładzie Krakowa. Przegl. Nauk. - Inż. i Kształtowanie Środowiska, 67, 54-66. 
Dockery D.W., Pope C.A., Xu X., Spengler J.D., Ware J.H., Fay M.E., Ferris B.G., Speizer F.E., 1993: An association between air pollution and mortality in six U.S. Cities. New England Journ. of Med., 329, 1753-1759.

Dzikuć M., 2017: Ekonomiczne i społeczne czynniki ograniczenia niskiej emisji w Polsce. Difin, Warszawa.

Edwards S., Jedrychowski W., Butscher M., Camann D., Kieltyka A., Mróz E., Flak E., Li Z., Wang S., Rauh V., Perera F., 2010: Prenatal exposure to airborne polycyclic aromatic hydrocarbons and children's intelligence at 5 years of age in a prospective cohort study in Poland. Environmental Health Perspectives, 118, 9, 1326-1331.

European Environment Agency, 2015: Air quality in Europe-2015 report. Publications Office of the European Union.

Houthuijs D., Breugelmans O., Hoek G., Vaskovi E., Miháliková E., Pastuszka J.S., Jirik V., Lolova D., Mieliefste K., Uzunova E., Volf J., 2001: $P M_{10}$ and $P M_{2,5}$ concentriatons in central and eastern Europe: results from the cesar study. Atm Environment, 35, 15, 2757-2771.

Jędryszkiewicz J., Piotrowski P., Pietras B., 2016: Koncentracja zanieczyszczeń pyłowych powietrza $P M_{2,5}$ w Krakowie w latach 2010-2014. Act. Geograph. Lodz., 104, 123-135.

Juda-Rezler K., Manczarski P., 2010: Zagrożenia zwiąane z zanieczyszczeniem powietrza atmosferycznego i gospodarka odpadami komunalnymi. Nauka, 4, 97-106.

Haczek A., 2014: Transformacja ustug przemystowych Bielska-Białej. Pr. Kom. Geogr. Przem. PTG, Uniw. Ped., Kraków, 159-183.

Kapka I., Zemła B.F., Kozłowska A., Olewińska E., Pawlas N., 2009: Jakość powietrza atmosferycznego a zapadalność na nowotwory pluc w wybranych miejscowościach i powiatach województwa śląskiego. Przegl. Epid., 63, 439-444.

Kondracki J. 2002: Geografia regionalna Polski. Wyd. Nauk. PWN, Warszawa.

Leśniok M., Caputa Z., 2009: The role of atmospheric circulation in air pollution distribution in Katowice Region (Southern Poland). Internat. Journ. of Environment and Waste Management, $4,62-74$.

Li Z., Sjodin A., Romanoff L.C., Horton K., Fitzgerald C.L., Eppler A., Aguilar- Villalobos M., Naeher L.P., 2011: Evaluation of exposure reduction to indoor air pollution in stove intervention projects in Peru by urinary biomonitoring of polycyclic aromatic hydrocarbon metabolites. Environment Internat., 37, 1157-1163.

Miller K.A., Siscovick D.S., Sheppard L., Shepherd K., Sullivan J.H., Anderson G.L., Kaufman J.D., 2007: Long-term exposure to air pollution and incidence of cardiovascular events in women. New England Journ. of Med., 356, 447-458.

Min J.Y., Min K.B., Cho S.I., Paek D., 2008: Combined effects of cigarette smoking and sulfur dioxide on lung function in Koreans. Journ. of Toxicology Environmental Health, 71, 5, 301-303.

Neupane B., Jerrett M., Burnett R.T., Marrie T., Arain A., Loeb M., 2010: Long-term exposure to ambient air pollution and risk of hospitalization with community-acquired pneumonia in older adults. Am. Journ. Respiratory Critical Care Med., 181, 1, 47-53.

Pénard-Morand C., Raherison C., Charpin D., Kopferschmitt C., Lavaud F., Caillaud D., Annesi-Maesano I., 2010: Long-term exposure to close-proximity air pollution and asthma and allergies in urban children. Eur. Respiratory Journ., 36, 1, 33-40.

Petryk A., 2018: Wplyw zanieczyszczenia powietrza na stan zdrowia mieszkańców a funkcjonalność miasta Krakowa. Journ. of Ecol. Eng., 19, 6, 124-131.

Radziszewska A., Karczmarek-Borowska B., Grądalska-Lampart M., Filip A., 2015: Epidemiologia, profilaktyka i czynniki ryzyka zachorowania na raka pluca. Pol. Merk. Lek., 38, 224, $113-118$.

Roczna ocena jakości powietrza w województwie ślaskim. Raport wojewódzki za rok 2018, 2019, Główny Inspektorat Ochrony Środowiska, Departament Monitoringu Środowiska, Regionalny Wydział Monitoringu Środowiska w Katowicach, Katowice. 
Rozporzadzenie Ministra Środowiska z dnia 10 sierpnia 2012 r. w sprawie stref, w których dokonuje się oceny jakości powietrza. Dz.U. 2012, poz. 914.

Rusin M., 2014: Urodzenia martwe i niska urodzeniowa masa ciała noworodków a jakość powietrza w województwie śląskim. Śląski Uniw. Med., Sosnowiec [rozpr. dokt.].

Sanyal M.K., Li Y.L., 2007: Deleteriuos effects of polynuclear aromatic hydrocarbons on blood vascular system of the rat fetus. Birth Defects Researtch, Part B, Developmental and Reproductive Toxicology, 80, 367-373.

Ścibor M., Balcerzak B., Czernecka Ż., Malinowska-Cieślik M., 2015: Ocena jakości życia pacjentów z astma oskrzelowa mieszkających $w$ Krakowie $w$ strefach różniacych się stężeniem pylu zawieszonego w powietrzu (PM10). Med. Środowiskowa, 18, 1, 45-53.

Trojanowska M., Świetlik R., 2013: Ocena ryzyka nowotworowego zwiazanego z narażeniem inhalacyjnym na benzo(a)piren $w$ wybranych miastach Polski. Med. Środowiskowa, 16, 2 , $14-22$.

Vassilev Z.P., Robson M.G., Klotz J.B., 2001: Outdoor exposure to airborne polycyclic organic matter and adverse reproductive outcomes: a pilot study. Am. Journ. of Ind. Med., 40, 255-262.

Wieczorek J., Wieczorek Z., 2011: Pobranie wielopierścieniowych węglowodorów aromatycznych z żywnościq. Bromatologia i Chem. Toksykologiczna, 44, 3, 725-731.

Wielgosiński G., Zarzycki R., 2018: Technologie i procesy ochrony powietrza. Wyd. Nauk. PWN, Warszawa.

Wormley D.D., Chirwa S., Nayyar T., Wu J., Johnson S., Brown L.A., Harris E., Hood D.B., 2004: Inhaled benzo[a]pyrene impairs long-term potentiation in the F1 generation rat dentate gyrus. Celluar and Mol. Biol. Letters, 50, 715-721.

$<$ www.katowice.pios.gov.pl> [dostęp: 4.08.2019].

$<$ www.katowice.stat.gov.pl> [dostęp: 4.08.2019]. 